\title{
"Characters" in Japanese Communication and Language: An Overview
}

\author{
Toshiyuki SADANOBU \\ Kobe University, Japan \\ sadanobu@kobe-u.ac.jp
}

\begin{abstract}
There are various ideas related to characters in modern Japan (dramatis personae, Ito's (2005) Kyara and its self-professed successors' ideas, and situation-based self). This paper will introduce these ideas, address my definition of character (situation-based self) in detail, and discuss its significance for communication and linguistic research.

The major characteristics of this definition are: (i) it is based on the traditionally taboo idea that "humans can change in response to the situation," and (ii) it is not something created by a researcher (the author), but was rather formed by speakers of Japanese in the course of daily life. I merely employed this word as it is, as a technical term.

Japanese speakers are keenly conscious of the self's situation-sensitiveness, but there is no need to think of Japanese society as unique just because it was the first to come out about this fact to the world. This characteristic of Japanese society can be understood as a difference of degree; that is, there is "a low degree of freedom in style, and a correspondingly large degree of freedom in character."
\end{abstract}

Keywords: character; style; personality; identity; Japanese

\section{Povzetek}

Raziskave navajajo različne teorije o likih v moderni Japonski (npr. dramska oseba, Itojev kyara in ideje njegovih samooklicanih naslednikov, značaji, ki temeljijo na posameznem primeru). Tokratna raziskava predstavlja te teorije, podrobno obravnava avtorjevo definicijo lika, ki temelji na posameznem primeru, ter razpravlja o njegovem pomenu $v$ komunikaciji in jezikoslovnih raziskavah.

Osnovne značilnosti definicije lika so naslednje: (i) definicija je osnovana na tradicionalno tabu ideji, da se lahko človek spreminja glede na situacijo, ter da (ii) lika ne ustvari raziskovalec (oz. avtor), ampak ga v vsakodnevnem pogovoru oblikujejo japonski govorci. Avtor tako poudarja, da že obstoječ izraz uporablja tudi kot termin v jezikoslovnih razpravah.

Japonski govorci se polno zavedajo lika, ki je občutljiv na določeno situacijo. Vendar zaradi tega, ker je svetu predstavila idejo o občutljivosti posameznika na situacijo, japonske družbe ni potrebno dojemati kot edinstvene. To značilnost japonske družbe lahko opišemo kot raznolikost stopenj občutljivosti; nizka stopnja svobode sloga ustreza visoki stopnji svobode lika.

Ključne besede: lik; slog; osebnost; identiteta; japonščina 


\section{Introduction}

Living in Japan today means being surrounded by characters. The streets are overflowing with products featuring popular characters, such as Hello Kitty and Pokémon. Moreover, nearly every locality has its own yuru-kyara - yurui (meaning weak but heart-warming) character - designed to promote regional vitalization. Unlike real people, who are complex multidimensional beings possessing various facets, such characters are more or less simplified one-dimensional beings. However, people not infrequently treat others, and even themselves, as one-dimensional beings that are like these characters.

Reflecting this situation, a variety of new ideas regarding characters have appeared in modern Japan. This paper will introduce these ideas, and discuss what significance one of them (the author's) has for communication and linguistic research. First, we will look at several ideas regarding characters.

\section{Several concepts related to characters}

As mentioned above, in modern Japan, one's daily life is surrounded by characters and, reflecting this fact, a large number of materials are being published about them. Among these are not only books written to entertain (e.g. Miura, 2004, 2013), but also those containing more or less academic ideas over a wide range of disciplines, including manga criticism (e.g. Ito, 2005; Iwashita, 2013), contemporary philosophy (e.g. Azuma, 2003; Uno, 2008; Okamoto, 2010), psychoanalysis (e.g. Saito, 2011), business studies (e.g. Odagiri, 2010), sociology (e.g. Senuma, 2007; 2009; Doi, 2009), literary criticism (e.g. Shinjo, 2009), cultural studies on modern society (e.g. Aihara, 2007, Kuresawa, 2010), media studies (e.g. Ogiue, 2008), and linguistics and communication theory (e.g. Sadanobu 2006; 2009; 2010-2012, 2011). In regards to yuru-kyara, there have been works that take into account regional government and national branding (e.g. Inuyama \& Sugimoto, 2012; Aoki, 2014).

However, these authors are in fact dealing with different objects. In my view, there are at least three different types of character (or similar phenomena). ${ }^{1}$ These different characters are as follows.

\subsection{Dramatis personae}

The first character type refers to people who appear in stories (dramatis personae). For example, this is the type of character one is discussing when looking at the problem of what kind of characters to include, and how to arrange them, when writing a story to attract the most readers. The yuru-kyara created for regional

\footnotetext{
${ }^{1}$ I will avoid mentioning the "characters" that are handled in logography, as this is clearly a different matter.
} 
vitalization can be called a subtype of this character. The second half of this portmanteau, kyara, is an abbreviation of the loan word kyarakutaa ${ }^{2}$, from the English word "character." Only this first type can be translated by the English word "character."

\subsection{Ito's (2005) Kyara}

The second type, written as Kyara, was introduced in manga criticism (Ito, 2005). It is highly specialized and distinct from the first type. Ito's definition of Kyara is given in (1).

(1) Most are depicted relatively simply using line art and are given names (or elicit the expectation of having names) to provide them with an impression of presence that is "something like a personality."

(Ito, 2005, p. 95)

Kyara in Ito (2005) must create the awareness in the reader, necessary to understanding the manga, that "the person shown in panel $A$ is the same person as the one in panel B." That is, they are the foundation for the identity of the beings portrayed in manga. With regards to all characters of the first type (dramatis personae) in the world of manga, Ito (2005) uses the concept of Kyara as a cornerstone, and rigorously distinguishes it from the first type of character, as can been seen in (2) below.

(2) On the foundation of the Kyara's sense of presence, a representation of a "body" in possession of a "personality" can be read, leading one to imagine that, behind the text, it has a "life" and "lifestyle." (author's emphasis)

(Ito, 2005, p. 96)

As mentioned earlier, the Japanese loan word kyarakutaa can be abbreviated as kyara, but this must be strictly distinguished from Kyara in Ito (2005). The Kyara in Ito (2005), of course, cannot be translated by the English word "character."

Quite distinct from the first type of character, this original concept of Kyara in Ito (2005) gained attention from advocates in many fields, beyond manga studies. It was employed in a variety of forms, for example in Kuresawa (2010, pp. 27-28): "Ito's framework certainly has enough scope to handle the entirety of modern society." We will look very briefly at some of these.

Aihara (2007) discusses various social situations using the keyword Kyara-ization (Kyara-ka); in other words, "living a Kyara-like life in real life" (p. 178). Specifically, Aihara refers to the phenomenon of people feeling a "Kyara-ized version of themselves" to be more accessible and real than their "real selves" as the "Kyaraization of identity." He calls the phenomenon of people yearning for the "Kyara-ized

\footnotetext{
${ }^{2}$ This word can also be written as "kyarakuta", omitting the final "a." Although I use one spelling consistently, there is no difference in meaning between kyarakuta and kyarakutaa; both are simply spelling variants.
} 
forms" illustrated in manga, and pursuing a live-action drama form of them in their "real bodies" the "Kyara-ization of the body." Finally, he deals with the recent phenomenon of the superficialization of communication among young people, i.e. the "Kyara-ization of communication." This keyword, "Kyara-ization," has been taken up in a variety of phenomena, such as the putting of manga into practice ("Kyara-ization of politics"), the tendency of emerging companies to present an exaggeratedly attractive corporate image detached from reality ("Kyara-ization of economics/enterprise"), and the phenomenon of people feeling attraction only to "parts" (Kyara-attributes) of products, but not the "whole" ("Kyara-ization of consumerism").

Doi (2009) argues that the uchi-Kyara (i.e. internal-Kyara, personality traits people are born with) form a compass for every person's life, while they perform soto-Kyara (i.e. external-Kyara) in response to interpersonal relationships; this is not limited to the young, but is common to all modern citizens.

Kuresawa (2010) is the most prominent author in terms of incorporating the distinction between the first character type versus Kyara in his discussion. The cover of his book bears the title in English: INTRODUCTION TO KYARAKUTAA CULTURE. Here, the word "KYARAKUTAA" is in a large font, with "KYARA" appearing especially large and in a different color from the remaining "KUTAA" (Figure 1). However, while the observations in Kuresawa (2010) extend to every corner of modern Japanese society, including yanki culture and pachinko, his ideas focus on the historical genealogy and popularity of the first type of character (dramatis personae), and his references to Ito's (2005) Kyara are very limited.

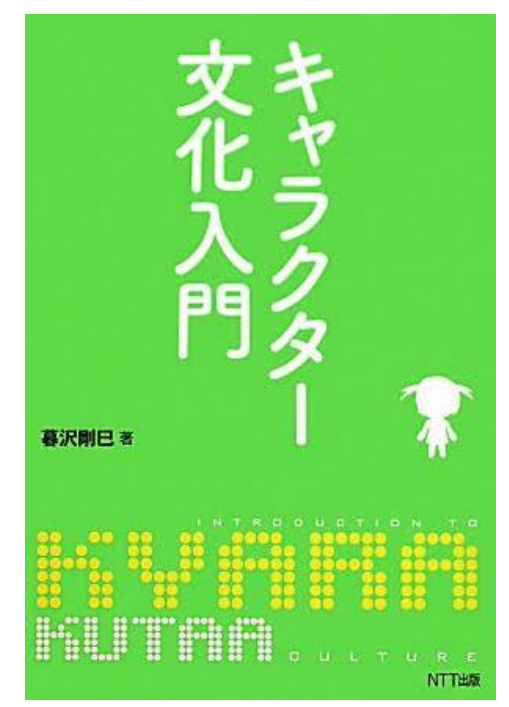

Figure 1: Cover of Kuresawa (2010)

Although, as hinted in the above summaries, these ideas contain fascinating observations, it is unclear how faithfully Ito's (2005) Kyara are being employed within 
them. Or, if they have undergone transformation, the extent of that transformation has not been clarified. Ito himself has expressed reservations on this matter. ${ }^{3}$

Rather than connecting these ideas with the Kyara from Ito (2005), perhaps it would be better to consider their connection to the third type, which will be described below.

\subsection{Situation-based self}

The third type of character, put succinctly, is the situation-based self. As it is something that Japanese speakers (young people in particular) have created during the course of everyday life, it has no formal English translation. However, having noticed the serviceability of this concept during my own communication and linguistic research, I decided to use the word "character" as my own specialized term to refer to this third type (e.g. Sadanobu, 2006; 2009; 2011).

As this report will ultimately try to illuminate communication in Japan and the Japanese language, hereafter, I will use "character" (sometimes abbreviated kyara) to refer only to this new concept, as applied to communication and language analysis, and not to dramatis personae nor to Ito's (2005) Kyara. No distinction in meaning will be made between character and kyara.

\section{Characters in Japanese communication}

This section will introduce my definition of character in detail, and discuss what significance it has for communication research.

\subsection{More than a style, less than personality}

I view character as a range of stability (i.e. unchangeability) in people, which is "more than a style, less than personality." First, we will review "style" and "personality."

"Style" has low stability, and can be changed overtly and intentionally without hindrance. For example, when asking for help from both the CEO of a client company and their own subordinate, a speaker might, with a bow of their head, politely say "I really appreciate your help with this matter," to the former, while slapping the latter on the shoulder and lightly intoning, "You too-please help with this." Even if observed by the subordinate making such a polite request to the client company's CEO, the speaker would not be particularly embarrassed. Nor would it be a problem for the speaker to be observed making a brusque request to his/her own subordinate by the client company's CEO. Here, in performing the communicative behavior [of

\footnotetext{
${ }^{3}$ See Sadanobu (2012, Feb 5-2015, Dec 6: No. 84-87, No. 86 inter alia) for details. http://dictionary.sanseido-publ.co.jp/wp/author/sadanobu/
} 
making a request about an established matter] the speaker switches style depending on his/her relationship with the listener. This fits the notion that "in order to achieve some established objective, people select an appropriate style in response to the situation and their personal relationships and carry out behaviors to accomplish their goals." For example, many teleological, intentional concepts predicated on pragmatics appear to be valid, such as non-natural meaning, inferential communication (Grice, 1957), informative intention, communicative intention, and ostensive-inferential communication (Sperber \& Wilson, 1986).

In contrast, "personality" is highly stable and not normally changed intentionally. If it is changed, this will cause a serious, fundamental shift that seems to make the speaker a "different person." For example, Toshio Shimao's novel Kisousha no Yuutsu (1964) contains the following part (3):

(3) "It's my fault. Please, don't go. I'll apologize. Don't go, please."

(...)

When he caught her in his arms, Nasu beat the glass door wildly with both hands, screaming anmaa (the word they used for "mother" on Nasu's home island). Her voice was strangely childish. Nasu tried to cast off Miichi's arms. Her strength was incredible. Miichi now tried earnestly to hold her back. "Anmai, wandaka, teretitabore (Mama, take me away)"

(...)

"Hage, nu-gakaya. (Oh, what happened?) What happened? What's wrong with me? Where am I? What is this place?"

(Toshio Shimao (1964) Kisosha no Yuutsu)

During the married couple's argument, the wife first says: "It's my fault. Please don't go. I'll apologize. Please don't go." in standard Japanese. Later she begins talking in her native island's dialect: Anmai, wandaka, teretitabore (Mama, take me away). Then she returns to standard Japanese when saying "What happened? What's wrong with me? Where am I? What is this place?" As indicated by the content of what she is saying, she has no memory of speaking in the island dialect. This is what is meant here by "personality."

Then, in the next example (4), is the change of kyara a change of style or a change of personality?

(4) Post here if your kyara at work is different from your regular character

1: Kotanuki: 12/06/03 15:37 ID: Main

At my part-time job, I'm very gloomy and dowdy, but at school I have a rowdy kyara. How about you?

2: Kotanuki: 12/06/03 15:41

Come to think of it, my kyara is different at home, work, with my boyfriend, and at school.[http://new.bbs.2ch2.net/test/read.cgi/kotanuki/1338705429/i] 
This is an excerpt from a post on the Internet forum "2 channel," in which the posters express that their kyaras are different for their "part-time job" and "school," and furthermore also at "home," and "with their boyfriends." Since it would be undesirable for the posters' school acquaintances to see their gloomy appearance at their job, or for their coworkers to see their cheery attitude at school, we can see that these kyaras are not something that can be overtly changed (discussed further in 2.3). This indicates that kyara is more stable than, and different from, "style." Moreover, since the posters are aware of their own changes of kyara and do not feel that they interfere greatly with their everyday life, we can infer that these kyaras are less stable than "personality." In other words, kyara is "more than a style, less than personality."

Of course, here we are talking about kyara as it is used on Internet forums in everyday language, not the specialized term "character." However, the specialized "character" as used in this paper is not qualitatively different from the everyday word kyara in (4). A specialized definition of "character" is given in (5):

(5) "Character" is something which ostensibly must not, or cannot, be changed intentionally. If changes in it are detected, this makes certain information obvious to the observer and the observed, making them both uncomfortable.

\subsection{A balancer for external and internal pressure}

In terms of concepts that largely resemble character as previously described, only the concept of juese in modern Chinese (see Kawasaki (2012) for a comparison with character) comes to mind. However, I believe that characters exist in every society although they run the gamut from clear to indistinct. In that they are the fulcrums (balancers) that result from humans balancing external and internal pressures, perhaps character is no different from "style" or "personality."

First we will look at an example that is easily understood. A geoduck can grow so large that its body cannot be covered entirely by its shell (Figure 2). It is quite different from the steamer clam, which will never outgrow its shell no matter how much it grows (Figure 3). However, the two varieties of clam are no different in that they are both balancing the external pressure of "needing to protect themselves" with the internal pressure of "needing to grow." What is important here is that there is not just one way of achieving this balance. There are cautious ways of achieving balance, like the steamer clam which places priority on external pressures and keeps its body wholly inside its shell, and then there is the way adopted by the geoduck, which has given up on protecting its body with its shell. As it does not seem that the geoduck is in danger of extinction, it seems that it has indeed achieved some kind of balance. Again, there is not just one way of achieving a balance between external pressures and internal needs. 


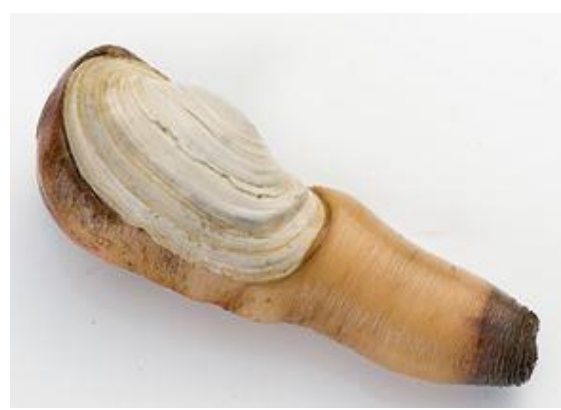

Figure 2: Geoduck

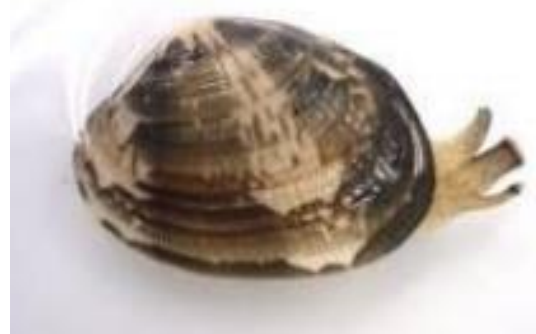

Figure 3: Steamer clam

What can be said of clams can also be said of humans. Humans too must balance external pressures and internal needs, and there is not just one way to do so.

Here, "external pressure" refers to the imperative to act appropriately in response to various social situations. School has its own situation, as does one's parttime job. In order to respond appropriately to various situations, humans must change in response to a particular situation.

On the other hand, here "internal pressure" refers to the desire to act in a way that is faithful to one's own individuality, regardless of the situation.

In the context of communication and language research, the idea that "humans change flexibly in response to the situation" is readily accepted without condition. From the functional perspective in particular, the general consensus seems to be that "dynamic" is regarded as "correct," while "static" is seen as "mistaken." However, in the real world flexible behavior is often criticized or mocked as "inconsistent" or "without pride." There are cases where "not changing in response to the situation" is celebrated. Such criticism of "inconsistency" can be found in the novel Shiroi Kyotoh, in which a vendor is portrayed negatively for responding flexibly to a situation by switching from an obsequious attitude to an arrogant one in dealing with a once good customer that has fallen on hard times and is on the verge of bankruptcy. He is told "you used to hover around the entrance to our shop, rubbing your hands together," and later is described as having "completely reversed his attitude" (Toyoko Yamazaki Shiroi Kyotoh (IV), 1969). There are also cases in which one's own pride allows no change, as in the case of Mrs. Tagawa in the novel Aru Onna, who is unable to respond flexibly when a young woman to whom she had initially behaved with condescension, suddenly becomes the center of attention: "At this point, Mrs. Tagawa was unable to change her attitude" (Takeo Arishima Aru Onna, 1911-13). As can be seen in Aesop's "Cowardly Bat" and the Martians in Ray Bradbury's The Martian Chronicles (1950), in other linguistic societies too those who respond too flexibly to a situation are not uncommonly said to be "doomed." The fact that in Japanese expressions such as bukiyo (clumsy), bukotsu (uncouth), kodawari (obsessiveness) and ganko (stubborn) are sometimes positively valued, demonstrates that inflexibility towards the situation is not necessarily considered to be a negative thing. 
In every society, it is the common wisdom that one tries to maintain a balance between external and internal pressures and respond somewhat flexibly to various situations while also maintaining some self-consistency (selfness). For this reason, just as the fingers each have a first, second, and third joint, the naturally occurring fulcrums (balancers) in humans are "personality," "character," and "style." It is hard to imagine that "character" is only found in Japanese society. Naturally, in other linguistic societies too "character" exists along with "personality" and "style," but it does not manifest itself as clearly as it does in Japanese society. The fact that "character" does not appear as clearly in many societies will be discussed in 3.3. The fact that characters can be seen to manifest along a spectrum ranging from clear to indistinct among different societies, and are especially clear in Japanese society, will be discussed in 3.5.

\subsection{Taboos of "polite society"}

As seen in (4), changes of "character" cannot be done overtly outside of the context of play (see the end of Section 3). We fear that changes in character in response to the situation will be discovered, and that this will lead to embarrassment. Sho Sakurai, a celebrity, admitted (6) that it would be "kind of awkward" if his antics on a variety show were seen by Nobutaka Murao, his costar on a serious news program:

(6) (When asked what guest would make him nervous) For me, it would be Mr. Murao. I've only ever met him in newscasting situations, so it'd be kind of awkward for him to see me yelling "Aha!!" on this show.

(http://www.pideo.net/video/youku/9315647f82fb246e/)

In this example, the speaker is afraid of his change in character (from the "serious" news program character to the "non-serious" variety show character) being detected, causing the other to think less of him - "I didn't know Mr. Sakurai had that side to him. He's always so serious on the news show. I thought he was a serious person. That's surprising." In Japanese society, behaving seriously tends to signify more than that one is using a serious style in that isolated occasion.

Put more rigorously, here the fear of discovery and embarrassment refers not to the discovery of the change of character as much as to the discovery of fakery - "I believed he was one kind of person, but the truth is different (it was a character)." The reason why people feel embarrassed if their faked personality is discovered is that the intentional putting on of a personality (including faked personalities) is a taboo in "polite society."

Even if it contains some authenticity, the intention to put on a personality violates this taboo. In the novel Sasameyuki, two men affect the manner of speech of a nobleman and a loyal friend, respectively. Although there was authenticity in these affectations (one really was of noble birth, the other was loyal, being the first to visit his ex-benefactor suffering from a flood), they become the object of dislike and contempt once their intentions to put on the airs of a "nobleman" and "loyal friend" 
are noticed (Jun'ichiro Tanizaki, Sasameyuki, Vol. II, 1947). The idea that "the speaker selects a style appropriate to the situation and controls his/her voice's speed and nasalization etc. in accordance with that style" appears very plausible. Still, as seen in the two examples from Sasameyuki, this idea does not in fact tell the whole story.

This aesthetics is not limited to the modern era. When Sei Shonagon wrote: "I despise it when people who are not so very old, or men, purposefully put on rustic airs" (Makura no Soshi Revised by Ikeda Kikan, Iwanami Shoten), it seems she was referring to violations of this same taboo. Thus, although I am sympathetic to other scholars who focus on communication among modern youths in discussing "character," I want to put some distance between them and myself. The notion of profile I am pursuing here can be seen more generally, and is not limited to modern youths.

"Polite society" depends on the convention of mutual recognition of "authenticity." In other words, in "polite society" you assume that I, the person before you, am authentic, and not deceiving you about my true identity. Similarly, I assume that you are authentic, and not falsifying your identity. Even after we part, I will be the same person, with respect to any other person, whether we meet 24 hours later, or 365 days later. I assume that you too are like this. This is why expressions like "there are a lot of facets to you," and "there's a lot about that person we don't know," have the potential to freeze a conversation if said aloud, even though they are, upon consideration, perfectly obvious. These are exactly the same, and would have the same chilling effect, as the question "is that a hairpiece?" This question smashes the "polite society" convention of assuming that we don't deceive others about our identity (baldness). Your hair is presumably real, and so is mine. While hairpieces do exist in the world, we assume that we, our friends, and everybody else have real hair. Because affecting a personality is a taboo that directly violates the "polite society" convention of mutually recognizing each other as "authentic," people worry about their affectations being detected, and feel ashamed of their affectations if they are noticed.

Of course, in keeping with this convention of polite society, the traditional view of humans is that "barring some extraordinary circumstance, such as the disintegration of one's personality, people do not change depending on the situation and are always authentic. What changes is the style, not the person; people change their style in response to the situation." What this simultaneously expresses is that faced with the reality that humans sometimes break with convention, we must recognize the existence of characters, and that contrary to the traditional view of humanity, sometimes not only style but the person as well can change with the situation.

If what I have said about "character" so far has given the reader the understanding that they are "personalities that can be used for a purpose," then I must say some intentional teleology has crept into the discussion. To be sure, there is much to overlap between characters and "personalities used for a purpose." However, this is not always the case. For example, consider (7): 
(7) Recently, feeling a bit like a criminal, I brought a fairly shy man, 12-years younger than myself, to a hot spring with my hot spring club. But the cause of my problems is that I always adopt the anego-kyara (...) I am not an anego -I'm not particularly elegant, nor am I quiet. I'm not aggressive when it comes to men either.

(http://ameblo.jp/kschaitian/entry-11170734947.html)

In this situation, the writer without realizing it, involuntarily falls into a certain character, a state of affairs with which she herself is not satisfied. Here, the anegokyara (i.e. female boss character) is not a "personality that the writer is intentionally wielding" to achieve some goal.

\subsection{A coming-out for the whole society}

Needless to say the conventions discussed earlier are important to those of us in "polite society." However, in reality it is impossible for us to obey these conventions and always let our natural selves show, no matter whom we are dealing with. In other words, we break these conventions and secretly put on affectations to make ourselves appear to be better than we really are.

In some cases, such affectation is sanctioned by a coming-out (public recognition), not on an individual level, but for society in overall. As stated above, the deception, such as a hairpiece is still basically taboo in Japanese society, but women's makeup, although similar insofar as it is an affectation, has undergone a society-level coming-out and has become less taboo, as evidenced by the abundance of makeup retailers in Japanese cities. In Japanese society, as discussed earlier (4), the fact that the word kyara is appearing in everyday language indicates this kind of coming-out is occurring for characters too.

Even so, as long as we try to remain the "polite society," conventions will be important; this coming-out is partial and limited. Putting on makeup in public, along with expressions like "heavy makeup" and "plaster on makeup," still have a negative image. Also, in contrast to "heavy makeup," the meaning of the expression "natural makeup" is currently wavering between "makeup that passes for one's natural face" (8) and "heavy makeup that passes for light makeup" (9).

(8) If done successfully, natural makeup makes you look pretty without it looking like you're wearing makeup. It emphasizes your attractiveness to the maximum possible extent without covering your face's characteristic features.

(http://josei.s353.xrea.com/MOTELU16.htm)

(9) Natural makeup is difficult! You don't want to look like you're wearing no makeup, but you want to look natural yet beautiful... natural makeup requires the highest degree of technique.

(http://ameblo.jp/misoziko/entry-11054732086.html)

In either sense, the appearance of artifice is mitigated (to zero or very little). 


\subsection{Characters, from the clear to the indistinct}

In Japanese society, whether or not a celebrity has undergone plastic surgery can be a source of gossip, but in Korean culture it can be performed with relatively little protest, indicating that coming-out manifests differently depending on the society. Among different societies there are also differences in the extent to which characters manifest clearly or indistinctly. From this, we can see that there is not just one way of achieving balance between external and internal pressures. Societies with a high degree of freedom regarding style have a low degree of freedom regarding characters, so their existence is indistinct. Societies with a low degree of freedom regarding style have a high degree of freedom regarding characters, so their existence is clear.

In general, Japanese-speaking society falls into the latter category. This can be ascertained by the above-mentioned appearance of the word "kyara/character" in everyday language, and the obsession with "complete coordination." One example is the assertion (10) that "idols don't go to the bathroom."

(10) Minamoto is an idol so he doesn't go to the bathroom!

(http://hiwihhi.com/takashi_shiina/status/1358814779547648)

Sometimes a foreigner will act very kindly and genially to one person, then treat another coldly. To the foreigner, this is nothing more than a change of style, but not uncommonly, the Japanese guests will be shocked-"I thought he was a 'good person,' but it was an act." Fune, from the manga Sazaesan, and flight attendants are examples of "good people," as they are always equally "good" to everybody, and never frown or use rough language.

By newly assigning a distinctly Japanese meaning to the foreign word "character" ((5) above), I am coming out about the fact that in recent Japanese society "people change with the situation." In this context, the existence of characters in Japanese society, as illustrated above, seems clear.

\subsection{Summary and supplements}

In sum, adopting the concept of a character in communication research is essential if we do not want to ignore "adversity" within communication. Not everybody, as pragmatics often holds, is the kind of fine person who "to achieve a given goal selects an appropriate style in response to the situation and interlocutor, and then behaves in accordance with this style, in order to accomplish that goal." For many people, communication is a source of distress. It is impossible for the assumption of "selecting an appropriate style to achieve a given goal" to explain the distress people feel when, regardless of intent, they find themselves shoved into specific characters in the course of their personal relationships, for example the person who worried about inconsistency discussed in (6), or the aforementioned anego-kyara discussed in (7). In 
order to highlight this "adversity" we need to adopt the concept of character and reign in and adjust the often rampant teleology.

However, it is noteworthy here that this anti-teleological feature of character need not always be obvious. As mentioned in 3.3, characters can overlap with fabricated personalities used for a purpose. In discussing the specificity of communication among young people in recent Japan, Fumiaki Senuma's paper (included in current issue) focuses on this side of intentional use of characters. This is fully compatible with my standpoint.

In the context of play, character can be changed publicly. Changes in character occur in conjunction with behavior. When a person engages in a certain behavior, $\mathrm{s} /$ he deploys the character that is skilled at it. For example, in the manga Doraemon, there is a scene in which Nobita talks to himself, using polite Japanese, saying kore wa taihen na mono desu yo (this is a terribly fine item) (Fujiko F. Fujio, Doraemon Vol. 7, Shogakkan, p. 159). In order to appraise and enjoy these items, which he has secretly obtained from Doraemon, he deploys the "appraiser" character (who speaks intelligently and politely), which is skilled at appraising (evaluating, assessing). A similar example can be seen in Dazai Osamu's Haru no Kareha (1946), so we have been doing this sort of "character play" for a long time. See Sadanobu (2009) for more details.

\section{Character in Japanese language}

Connections between a character and a language are diverse. Below, I will introduce these connections, explain one that this special report particularly illuminates, and discuss the significance of adopting the concept of a character in linguistic research.

\subsection{Four connections between characters and language}

There are at least four connections between characters and language. (These four are not mutually exclusive.)

First, language can directly express character, just as the Japanese word botchan (rich male kid) indicates a "self-centered male," regardless of age.

Secondly, as already mentioned, language (e.g. the Japanese word ore), in addition to expressing meaning (e.g. the speaker; "I"), can implicitly express the character of the speaker ("an unrefined male"). I refer to the speech-producing character as the "speaker's character," and call the language such characters produce, taking a cue from Satoshi Kinsui, "role language." What is important is that unlike "role" in its everyday sense, role language, as in (11), is defined in a form that does not include teleology.

(11) When we can imagine a specific profile (age, gender, occupation, status, era, features, appearance personality, etc.) from a specific language usage 
(vocabulary, wording, expressions, intonation, etc.), or when we are presented with a specific profile and can imagine the type of language people of that profile will probably use, this is called role language.

(Kinsui 2003)

Kinsui has since narrowed this definition of the concept of role language somewhat. See Kinsui's paper (in current issue) for details. (However, here I will use the definition from (11), unaltered, for role language.)

Thirdly, language that expresses an action also implicitly expresses the character that is performing that action, just as nitarito hokusoemu (chuckle grimly) conveys a "villain's" manner of laughing. In this case, the character is referred to as the "referent's character."

Fourthly, language that expresses a thought can also implicitly express the character of a thinker (the "thinker's character). While the thinker's character is similar to the speaker's character, the two are not the same. For example, while a speaker who is a refined lady character would not say "Can't something be done?" (nantoka naranai ka) or "that seems sketchy" (nandaka ayashii na), this observation does not apply when she is thinking to herself, as shown in (12) and (13)

(12) "Can't something be done?" the peeress thought earnestly.

(13) I thought it seemed sketchy too.

When thoughts emerge as words, our ability to use them is a case of words becoming a sort of work of art or product. In other words, the conceptualized character becomes the thinker's character, acting as illustrator. On this point, the thinker's character is relevant not only to the speaker's character, but also to the referent's character.

As many of the articles in this report are focused on the third of the above four connections, I want to discuss the second (connection between speaker's character and role language) below. For the details of the other three connections, see Sadanobu (2012, Feb 5-2015, Dec 6).

\subsection{Two types of speaker's characters}

Role language is indeed seen in other languages. Here two categories of speaker's character are relevant: the "Us" type and "Foreigner" type.

The "Us" type is a resident of the modern community of standard Japanese speakers, for which four scales are assumed to exist: "gender" (male/female), "age" (elderly/middle aged/youth/child), "status" (high/low), and "class" (refined/vulgar).

All others are "Foreigner" type characters. These correspond with characters such as the "Space Alien" who says Chikyujin ni tsugu. ("Attention, earthlings.") with monotonous flat intonation, the "Heian Aristocrat" who says Maro wa... de ojaru ("I 
am..."), the "Westerner" who says Nihonominasan koniichiwa! ("Hello everyone in Japan!"), the "Country Folk" who say Ora, waganne ("I don't know."), and the "Cat" who says Sore wo nya, nanto ka nya.... ("That is -meow- something about -meow-...").

While "Us" type characters exist densely on the four scales, "Foreigner" types occur only sporadically; e.g. there is a "Heian Aristocrat" character but no "Heian Commoner." "Foreigner" type speaker characters, such as the "Ancient Noble," "Politician," or "Soldier" are seen as speakers of foreign languages; so the heart of the problem is the "Us" types.

Although it is well-known that Japanese language has a lot of first person pronouns such as watashi, washi, atashi, asshi, atai, ore, oira, and boku (e.g. Siewierska 2004), role language is not limited to the first-person pronouns. We can find role language in the ubiquity of Japanese speech. It is not uncommon for the speaker's character to be revealed by just a single word. For example, soreo-da-ne would be used by an "Older Man" kyara, soreo-ja-na by a "Senior Citizen" kyara, soreo-yo (in rising intonation) by a "Woman" kyara, and soreo-yo (in sharply rising and falling intonation) by a "Vulgar Man" kyara, although all of these phrases would translate into English as "it."

Speaking Japanese appropriately requires one to think first about the speaker's character. This is why learners of Japanese sometimes sound strange when they use textbook Japanese or Japanese they learned verbatim from a significant other who natively speaks Japanese. It is a large problem in Japanese language education and learning. Yukiko Shukuri's article (in current issue) addresses this problem based on her experiences as a Japanese instructor.

\subsection{Summary and supplements}

The above undermines the legitimacy of the thesis that "Japanese is the same, no matter who uses it." In reality, many kinds of Japanese are being spoken, depending on the speaker's character ${ }^{4}$. Accepting this reality requires that we implement the concept of characters in Japanese language research.

Details of this can be found in Kenji Tomosada's article (in current issue), but here I will very briefly introduce two examples of this phenomenon.

The first phenomenon is related to the prosody of interjections. There are dozens of interjections in Japanese, just in the common language. Heretofore, the prosody of these has remained unclear. In simplified terms, it was understood only that, for example, the interjection of surprise ara can be said with either a rising or falling intonation. In adopting the concept of characters we, receive the principle that "interjections of surprise are said with a rising intonation." This principle seems feasible, considering that when surprised, the voice shifts from a low intonation,

\footnotetext{
${ }^{4}$ While it does not focus on character, Iwasaki (2005) is also opposed to this thesis, instead examining the diversity in the real Japanese language.
} 
reflecting the speaker's composed state, to a high one, reflecting an agitated state. So, why can ara be said with a falling intonation, in departure from this principle? This is a specialized pronunciation, limited to speakers with a "refined" character. When reading aloud the sentence Hako wo akete mireba ara fushigi ("When I opened the box -oh! It was mysterious") from a story, the reader's interjection expresses not only his/her own, but the story's protagonist's, surprise. This interjection is usually read with a falling intonation. That is, interjections that express the surprise of others are said with a falling intonation. We are deferential when expressing surprise on behalf of others, as a speaker with a refined character would call for refinement. This is the story behind the shifting intonation of ara. Thus, by employing the concept of character, we can neatly clear up phenomenon that had appeared confusing until now. See Sadanobu (2015) for detail.

The second phenomenon has to do with environments in which kyara-joshi (character-particles) occur. Traditionally, shu-joshi (sentential-final particles) such as yo, na, and ne, which can appear at the ends of Japanese sentences, were thought of as a closed set of attitudinal words. In reality, words may appear after the shu-joshi that are related to not the speaker's attitude, but to his/her character (e.g. uso-da-yopyo- $n$, "Just kidding-pyo- $n$ "). This is limited to the context of play, but by examining similar cases in regional dialects, one can observe parallel phenomena without this limitation. For example, natives of the Matsushima coast of Miyagi Prefecture, when asking "Aren't there any pickles?" -oshinko wa arimasen ka? in standard Japanesesay oshinko neesu-ka-wa? After the interrogative shu-joshi $k a$, they add the 1st person pronoun wa (i.e. I), expressing identity (Fujiwara, 1994, p. 238). As shown above, the concept of character offers an opportunity to fundamentally reappraise sentence structure (Sadanobu, 2007). Kenji Tomosada's article (included in current issue) further explores this issue from the perspective of regional dialects.

\section{Conclusions}

This article introduced various ideas related to characters circulating in modern Japan (dramatic personae, Ito's (2005) Kyara and its successors' ideas, and situation-based self). It dealt with my own definition of character (situation-based self) in detail, and discussed its significance for communication and linguistic research.

The major characteristics of my definition are: (i) it is based on the traditionally taboo idea that "humans can change in response to the situation," and (ii) it is not something created by researchers (the author), but rather was formed by speakers of Japanese in the course of daily life. I merely employed this word, as-is, as a technical term as I thought it conveyed the keen awareness of the speakers with respect to communication and language in Japan.

However, Japanese speakers are highly conscious of the self's situationsensitiveness, but there is no need to think of Japanese society as unique just because it was the first to come out about this fact in coining the loan word kyarakutaa with 
this new meaning. Of course, the context in which the heretofore taboo idea that people change in response to the situation, together with the word kyarakutaa, rapidly spread and took root, must be thought of as distinct to Japanese society. Yet, I believe that it is perhaps sufficient to think about that context as a relative difference of degree, i.e. "a low degree of freedom in style, and a correspondingly large degree of freedom in character."

If this is the case, the significance of character to communication and linguistics would not be limited to Japan, but should be similar for other language communities, albeit to differing extents. So, my hope is that this article will provide opportunities for character-related cross-cultural research on communication and languages.

Additionally, "character" is not a theory that is in competition with Mikhail Bakhtin's polyphony, Erving Goffman's self-presentation, Elinor Ochs's social identity, John Gumperz's contextualization, or moreover critical discourse analysis. While character is a concept that is consciously recognized and mentioned by many native speakers of Japanese in daily life, it is not a theory. It is merely a concept that I have included in my own research framework. So, character is not something that stands within a competitive relationship to those other conceptual frameworks. Rather, the concept of character can be incorporated into many theories to increase their descriptiveness.

If one were to speak of competition between theories in relation to character, it would be between theories that can incorporate the concept of character and those that cannot. Theories that recognize only conscious behaviors as human communicative behaviors cannot accept characters. Such theories do not handle unconscious phenomena - e.g. A unintentionally yawns, causing B to yawn too; $A$ begins to cry, causing $B$ to empathetically begin crying too- as communicative phenomena. These theories have a traditional view of humanity, which assumes that people can only change their styles according to the situation to achieve goals. According to this view, the person's style may change in response to the situation, but the person him/herself does not (barring multiple personality disorder), regardless of the situation. In other words, it is this traditional view of humanity that cannot accept the phenomenon of characters.

\section{Acknowledgements}

I thank Prof. Andrej Bekeš for giving us such a precious opportunity. This work was partially supported by the Ministry of Education, Culture, Sports, Science and Technology, Grant-in-Aid for Scientific Research (A), 23242023 and 15H02605. 


\section{References}

Aihara, H. (2007). Kyara-ka suru Nippon. Tokyo: Kodansha.

Aoki, S. (2014). Kyarakutaa, pawaa: Yuru-kara kara kokka burandingu made. Tokyo: NHK Books.

Azuma, H. (2003). Doubutsukasuru otakukei bunka. In H. Azuma (Ed.), Moujougenron efu kai: Posuto modan, otaku, sekushuariti (pp. 19-38). Tokyo: Seidosha.

Doi, T. (2009). Kyara-ka suru/sareru kodomotachi: Haijogata shakai niokeru aratana ningenzou. Tokyo: Iwanami Shoten.

Fujiwara, Y. (1994). Bunpougaku. Tokyo: Musashino Shoin.

Grice, H.P. (1957). Meaning. Philosophical Review, 66 (3), 377-388.

http://www.jstor.org/stable/2182440?origin=JSTOR-pdf\&seq=1\#page_scan_tab_contents

Inuyama, A., \& Sugimoto, M. (2012). Yuru-kyararon: Yurukunai "yuru-kyara" no jittai. Tokyo: Voyager.

Ito, G. (2005). Tezuka izu deddo: Hirakareta mangahyougenron e. Tokyo: NTT Publishing Co.

Iwasaki, S. (2005). Multiple-grammar hypothesis: A case study of Japanese passive constructions. Paper presented at Phylogeny and Ontogeny of Written Language, Kyoto University, August 17, 2005.

Iwashita, H. (2013). Shoujomanga no hyougenkikou: Hirakareta mangahyougenshi to "Tezuka Osamu". Tokyo: NTT Publishing Co.

Kawasaki, M. (2012). Hanyu "juese yuyan" yanjiu (Unpublished dissertation). Huazhong University of Science and Technology, China.

Kuresawa, T. (2010). Kyarakutaa bunka nyuumon. Tokyo: NTT Publishing Co.

Miura, J. (2004). Yuru-kyara daizukan. Tokyo: Fusosha.

Odagiri, H. (2010). Kyarakutaa towa nanika. Tokyo: Chikuma Shobo.

Ogiue, C. (2008). Netto ijime: Webushakai to owarinaki "kyara" sensou. Tokyo: PHP Institute.

Okamoto, Y. (2009). Juunisaikara no gendaishisou. Tokyo: Chikuma Shobo.

Sadanobu, T. (2006). Kotoba to hatsuwa kyarakuta. Bungaku, 7 (6), 117-129.

Sadanobu, T. (2007). Kyara-joshi ga arawareru kankyou. In S. Kinsui (Ed.), Yakuwarigo kenkyu no chihei (pp. 27-48). Tokyo: Kurosio Publishers.

Sadanobu, T. (2009). Metamorphosis in Japanese manga and our daily communication. Studii de Ştiinţă şi Cultură, 5 (1) 16-25. http://www.revista-studiiuvvg.ro/images/stories/16/metamorfoza.pdf

Sadanobu, T. (2011). Nihongo shakai nozoki kyarakuri: Kaotsuki, karadatsuki, kotobatsuki. Tokyo: Sanseido. 
Sadanobu, T. (2010, Mar 14-2012, Feb 26). An unofficial guide for Japanese characters. (English translation of the draft of Sadanobu (2011)) Senseido Word-Wise Web. Retrieved from http://dictionary.sanseido-publ.co.jp/wp/author/sadanobu-e/

Sadanobu, T. (2012, Feb 5-2015, Dec 6). Nihongo shakai nozoki kyarakuri hoi. (A supplement to Sadanobu (2011)) Sanseido Word-Wise Web. Retrieved from http://dictionary.sanseido-publ.co.jp/wp/author/sadanobu/

Sadanobu, T. (2015). Kandoushi to naibujoutai no musubitsuki no meikakuka nimukete. In K. Tomosada (Ed.), Kandoushi no gengogaku (pp. 3-14). Tokyo: Hitsuji Shobo.

Saito, T. (2011). Kyarakutaa seishinbunseki: Manga, bungaku, Nihonjin. Tokyo: Chikuma Shobo.

Senuma, F. (2007). Kyararon. Tokyo: Studio Cello.

Senuma, F. (2009). Naze wakai sedai wa "kyara"-ka surunoka. Tokyo: Kasga Publishing Inc.

Shinjo, K. (2009). Monogatari kougakuron: nyuumonhen kyarakutaa o tsukuru. Tokyo: Kadokawa Gakugei Shuppan.

Siewierska, A. (2004). Person. Cambridge: Cambridge University Press.

Sperber, D. \& Wilson, D. (1986). Relevance: Communication and Cognition. Oxford: Basil Blackwell.

Uno, T. (2008). Zeronendai no souzouryoku. Tokyo: Hayakawa Shobo. 
